\title{
Teaching with technology in higher education: understanding conceptual change and development in practice
}

\section{Claire Englund, Anders D. Olofsson \& Linda Price}

To cite this article: Claire Englund, Anders D. Olofsson \& Linda Price (2017) Teaching with technology in higher education: understanding conceptual change and development in practice, Higher Education Research \& Development, 36:1, 73-87, DOI: 10.1080/07294360.2016.1171300

To link to this article: https://doi.org/10.1080/07294360.2016.1171300

\section{Published online: 12 Apr 2016.}

Submit your article to this journal $₫$

III Article views: 6597

Q View related articles ¿

View Crossmark data

Citing articles: 59 View citing articles $\sqsubset$ 


\title{
Teaching with technology in higher education: understanding conceptual change and development in practice
}

\author{
Claire Englund $^{\mathrm{a}}\left(\mathbb{D}\right.$, Anders D. Olofsson $^{\mathrm{a}}$ (D) and Linda Price ${ }^{\mathrm{b}}$ (D) \\ ${ }^{\mathrm{a} D e p a r t m e n t ~ o f ~ E d u c a t i o n, ~ U m e a ̊ ~ U n i v e r s i t y, ~ U m e a ̊, ~ S w e d e n ; ~}{ }^{\mathrm{b} C e n t r e ~ f o r ~ H i g h e r ~ E d u c a t i o n ~ R e s e a r c h ~ a n d ~}$ \\ Practice (CHERP), Kingston University, Kingston-upon-Thames, London, UK
}

\begin{abstract}
Research indicates that teachers' conceptions of and approaches to teaching with technology are central for the successful implementation of educational technologies in higher education. This study advances this premise. We present a 10-year longitudinal study examining teachers' conceptions of and approaches to teaching and learning with technology. Nine teachers on an online Bachelor of Science in Pharmacy and a Master of Pharmacy programme at a Swedish university were studied using a phenomenographic approach. Results showed clear differences between novice and experienced teachers. Although novice teachers initially held more teacher-focused conceptions, they demonstrated greater and more rapid change than experienced colleagues. Experienced teachers tended to exhibit little to no change in conceptions. Supporting conceptual change should, therefore, be a central component of professional development activities if a more effective use of educational technology is to be achieved.
\end{abstract}

\section{ARTICLE HISTORY}

Received 10 December 2015 Accepted 15 March 2016

\section{KEYWORDS}

Conceptual change;

conceptions of and approaches to teaching; educational technology; higher education; teaching with technology

\section{Introduction}

Over the last 25 years, educational technology (Edtech) ${ }^{1}$ in Higher Education (HE) has been promoted as having the potential to transform teaching and learning (Conole, 2014; Laurillard, 2008). Even so, there is little evidence of the long promised revolution in HE facilitated by Edtech (Conole, de Laat, Dillon, \& Darby, 2008; Kirkwood \& Price, 2013; Olofsson \& Lindberg, 2014; Price \& Kirkwood, 2014b; Selwyn, 2010). There is a growing need for educational research to account for the distinct 'digital disconnect' between the enthusiastic rhetoric and rather uninspiring reality of university Edtech use (Selwyn, 2007) and to develop strategies to facilitate the implementation of Edtech in HE to enhance student learning (Ertmer \& Ottenbreit-Leftwich, 2013; OttenbreitLeftwich, Glazewski, Newby, \& Ertmer, 2010).

A critical factor in the successful implementation of Edtech in HE has been identified as the competence of teachers to know why, when and how best to implement educational technologies (Krumsvik, 2014; Laurillard \& Masterman, 2009; Lindberg \& Olofsson, 2012; Schneckenberg, 2009, 2010). The adoption of Edtech by teachers is, however, a 
complex process influenced by many factors both extrinsic and intrinsic (Drent \& Meelissen, 2008; Errington, 2004; Price, 2014; Somekh, 2008). How teachers use technology is the focus of much research; however, consideration of more fundamental questions such as teachers' conceptions of and approaches to teaching and learning with Edtech is missing (Kim, Kim, Lee, Spector, \& DeMeester, 2013; Kirkwood, 2009; Kirkwood \& Price, 2006; Price, 2014; Somekh, 2008).

There is a need to research change and development in teachers' conceptions of and approaches to the use of Edtech over time if the relatively ineffectual implementation of Edtech is to be remedied. This paper presents a 10-year longitudinal study (2004-2014) with the objective of revealing variations and changes in conceptions and approaches to teaching with technology of teachers in HE over time. Nine teachers working on an online Bachelor of Science in Pharmacy and Master of Pharmacy programmes at a Swedish university are studied, using a phenomenographic approach to analyse the interview data (Trigwell, Prosser, \& Taylor, 1994).

\section{Conceptions of and approaches to teaching and learning}

The use of the terms 'conceptions' and 'approaches' to teaching in this study follows Kember's (1997) definition:

- Conceptions of teaching are defined as the individual's beliefs about teaching and learning.

- Approaches to teaching and learning are defined as the strategies teachers adopt for their teaching practice.

Although conceptions and approaches are defined by Kember as separate aspects of teaching, these two concepts are theoretically closely aligned (Norton, Richardson, Hartley, Newstead, \& Mayes, 2005). Trigwell and Prosser (1996) argue that teachers' approaches to teaching correspond to their conceptions of teaching, which in turn relate to their conceptions of learning. In this study, the more discernible changes in approach are seen as indicative of a corresponding change in conceptions of teaching with Edtech.

Approaches to using Edtech in teaching and learning have been found to be underpinned by conceptions of technology use in education, conceptions of teaching and learning and perceptions of the technological teaching context (Kim et al., 2013; Kirkwood \& Price, 2012; Song \& Looi, 2012). Thus, how teachers conceptualise Edtech and the role of teaching has a significant impact on how they utilise technology in their teaching practice (Kirkwood \& Price, 2012; Price \& Kirkwood, 2014a).

The concept of a 'teaching approach' is used varyingly with some researchers seeing it as relatively stable (Kember \& Kwan, 2000), while others agree that context affects teaching approaches (Fanghanel \& Trowler, 2008; Prosser \& Trigwell, 1999). A student-centred approach is consistently viewed as more sophisticated than a teacher-centred approach (Kember \& Gow, 1994), and is considered to be necessary for the successful integration of Edtech (Glassett \& Schrum, 2009; Somekh, 2008). Trigwell and colleagues (1994) identified five qualitatively different approaches to teaching (A to E) that are structurally related 
in a hierarchy of inclusiveness, ranging from information transmission to facilitating learning through conceptual change.

The consequences of these differing approaches lie in the manner in which they influence how technology is used to facilitate learning. Content-focused teaching is likely to manifest itself in technology use for the presentation of information. Comparatively, a learning-focused use of technology allows students to demonstrate their understanding of a topic (Kirkwood \& Price, 2013). It is important for teachers to perceive and use technology as an integral part of a student-centred approach to teaching if enhanced learning outcomes are to be achieved (Åkerlind, 2003; Cope \& Ward, 2002; Glassett \& Schrum, 2009; Kim et al., 2013; Kreber \& Kanuka, 2013).

There are an increasing number of studies that examine teachers' approaches to teaching and their conceptions of teaching in HE (Biggs, 1999; Kember \& Kwan, 2000; Kirkwood \& Price, 2012). Few studies, however, have sought to understand changes in HE teachers' conceptions of and approaches to teaching and learning with technology over time (Orlando, 2014; Scott, 2016).

\section{Methods}

A mixed-method approach (Cohen, Manion, \& Morrison, 2011) was adopted collecting quantitative and qualitative data. The advantages include increased confidence in research findings and data triangulation through understanding the issues from a range of perspectives (Cohen et al., 2011; Creswell, 2002; Thurmond, 2001). Contextual and personal factors may also contribute to changes in conceptions over time; therefore, qualitative data such as teacher interviews were combined with quantitative data from student evaluations of teaching. Table 1 illustrates the contribution of the different sources of data used in the mixed-methods research design.

\section{Context}

This 10-year longitudinal study (2004-2014) encompassed data from a Bachelor of Science in Pharmacy (BPharm) and from 2010 onwards also from a Master in Pharmacy (MPharm) programme at a Swedish university. The programmes were delivered almost entirely online and teachers frequently acted as tutors on both programmes. For the delivery of digital course materials and administration, a virtual learning environment (VLE) ${ }^{2}$

Table 1. Mixed-methods research design.

\begin{tabular}{|c|c|c|c|}
\hline Method & Sampling regime & Rational & Sample size \\
\hline $\begin{array}{l}\text { Interviews with } \\
\text { teachers }\end{array}$ & $\begin{array}{l}\text { Purposive sampling. Teachers with } \\
10 \text { years' experience of the } \\
\text { programmes }\end{array}$ & $\begin{array}{l}\text { To investigate the conceptions of and } \\
\text { approaches to teaching \& teaching with } \\
\text { technology over time }\end{array}$ & $\begin{array}{l}\text { 2004: } 7 \\
\text { teachers } \\
\text { 2008: } 6 \\
\text { teachers } \\
\text { 2011: } 7 \\
\text { teachers } \\
\text { 2014: } 9 \\
\text { teachers }\end{array}$ \\
\hline $\begin{array}{l}\text { Course evaluations } \\
\text { by students }\end{array}$ & $\begin{array}{l}\text { Selected questions from course } \\
\text { evaluations 2004, 2008, } 2011 \text { and } \\
2014\end{array}$ & $\begin{array}{l}\text { Student satisfaction with teaching over time. } \\
\text { Triangulation of information from teacher } \\
\text { interviews }\end{array}$ & See Table 6 \\
\hline
\end{tabular}


was used. Students were allocated to study groups and assigned an experienced pharmacist as their tutor. Lectures, seminars and tutorials as well as teacher-student communication and student-student communication were facilitated by means of the VLE, Adobe Connect $^{\circledR}, 3$ e-mail and discussion forums. From 2008 Wikis and podcasts were included and from 2011 a virtual immersive 3-D environment, OpenSim ${ }^{\circledR}, 4$ was also implemented. The use of technology on the programme was blended with personal meetings with local tutors and laboratory work. More than thirty teachers were involved in the development and implementation of the programme, although only approximately one-third have been engaged with the programme for the entire 10-year period studied. Table 2 illustrates student and teaching staff numbers for the programmes.

\section{Respondents}

Lecturers and students participated in interviews and completed questionnaires at four points over the 10-year period. To facilitate the longitudinal design, purposive sampling of the teachers was necessary to select participants within the time span (Cohen et al., 2011). Four experienced teachers, and five novice teachers were chosen, four males and five females. Online course evaluation questionnaires for each course were completed by students. There is a complete data set for nine teachers.

The four male respondents were lecturers in the fields of chemistry, pharmacology, biology and statistics. The five female teachers work in the fields of pharmacy and clinical pharmacology. Table 3 shows the pseudonyms of the participants, programmme taught on and subject. Also listed is their prior teaching experience with and without Edtech and teacher professional development education.

Table 2. Number of teachers and students on the programme.

\begin{tabular}{|c|c|c|c|c|}
\hline & 2004 & 2008 & 2011 & 2014 \\
\hline Number of teachers & 30 & 30 & 36 & 36 \\
\hline Number of students & 110 BPharm & 88 BPharm & $\begin{array}{l}53 \text { BPharm } \\
20 \text { MPharm }\end{array}$ & $\begin{array}{l}43 \text { BPharm } \\
20 \text { MPharm } \\
20 \text { BPharm \& MA }\end{array}$ \\
\hline
\end{tabular}

Table 3. Respondents, subject taught, teaching experience and professional development.

\begin{tabular}{|c|c|c|c|c|c|c|}
\hline $\begin{array}{l}\text { Pseudo- } \\
\text { nym }\end{array}$ & Gender & $\begin{array}{c}\text { Programme } \\
\text { taught on }\end{array}$ & Subject area & $\begin{array}{c}\text { Teaching experience: } \\
\text { no. yrs on campus } \\
2004\end{array}$ & $\begin{array}{c}\text { Teaching } \\
\text { experience: no. yrs } \\
\text { online } 2004\end{array}$ & $\begin{array}{l}\text { Teacher professiona } \\
\text { development } 2004\end{array}$ \\
\hline Larry & M & BSc Pharm & Chemistry & 30 & 0 & None \\
\hline Harriet & $\mathrm{F}$ & BSc Pharm & Pharmacy & 0.6 & 0 & None \\
\hline James & $M$ & $\begin{array}{c}\text { BSc Pharm } \\
\text { MPharm }\end{array}$ & Chemistry & 0.2 & 0 & 4 weeks \\
\hline Rolf & M & BSc Pharm & $\begin{array}{l}\text { Biology/ } \\
\text { Physiology }\end{array}$ & 33 & 10 & 6 weeks \\
\hline Martha & $\mathrm{F}$ & BSc Pharm & Pharmacology & 0 & 0 & None \\
\hline Susan & $\mathrm{F}$ & $\begin{array}{c}\text { BSc Pharm } \\
\text { MPharm }\end{array}$ & Pharmacology & 0 & 0 & None \\
\hline Steven & $M$ & BSc Pharm & Pharmacology & 9 & 0 & 6 weeks \\
\hline Paul & $M$ & BSc Pharm & Statistics & 20 & 0 & 6 weeks \\
\hline Maggie & $\mathrm{F}$ & $\begin{array}{c}\text { BSc Pharm } \\
\text { MPharm }\end{array}$ & $\begin{array}{l}\text { Clinical } \\
\text { Pharmacy }\end{array}$ & 0 & 0 & None \\
\hline
\end{tabular}


The uneven distribution of teaching experience and field of expertise between male and female participants can be related to the fact that the pharmacy profession has become increasingly feminised (Hawthorne \& Anderson, 2009; Stanfors, 2007). In 2003 the Department of Clinical Pharmacology recruited several experienced pharmacists, all of who were female and without prior teaching experience, resulting in a gender balance of $71 \%^{5}$ female staff. In contrast, the chemistry and biology departments employ many experienced teachers, predominately male $(78 \%){ }^{6}$

Semi-structured interviews with teachers were carried out in 2004, 2008, 2011 and 2014 to elicit the approaches to teaching and underlying conceptions and motives that informed their use of Edtech. These were conducted with a focus on understanding issues around

- teacher identity

- conceptions of teaching and learning

- perceptions of the teaching context

- perceptions of the technology context and beliefs about teaching with Edtech.

All interviews were approximately one hour in length. The interviews were conducted in Swedish and translated by author 1, and were verified by author 2. The interviewees' contributions were anonymised and stored according to research ethics regulations (British Educational Research Association, 2011; Swedish Ethical Review Board, E, 2004). Qualitative software (NVIVO ver.10) was used to record, store and organise the data.

Student course evaluations were used to provide an indication of student satisfaction with the quality of teaching on the programme. Increasing evidence suggests that they are valid and reliable indicators (Benton, Cashin, \& Kansas, 2012; Marsh, 1987; Spooren, Brockx, \& Mortelmans, 2013). Two questions in congruence with Ramsden's (1991) Course Experience Questionnaire (CEQ) were used to indicate student satisfaction with teaching quality and aspects such as course design, delivery and examination:

Q1: I am satisfied with the support provided by the teacher on this course.

Q2: Overall I am satisfied with the quality of this course.

These were scored on a Likert scale of 1 to 6 , where $1=$ do not agree and $6=$ agree entirely. An average of the mean values of the students' responses to the two questions was used to illustrate student satisfaction with the courses taught by the respondents. We averaged the results of Q1 on student satisfaction with teaching and Q2 on satisfaction with the course as a whole to increase the validity of data on student satisfaction. Results are shown in Figure 1. Table 6 illustrates the response rates and mean scores for each question.

\section{Interview data analysis}

Following Trigwell and colleagues (1994), a phenomenographic approach was adopted in the analysis of the interview material. The data were not regarded as yielding a literal representation of reality, but as a narrative of respondents' perceived conceptions and approaches to teaching. The five categories of approaches to teaching (Trigwell et al., 1994) were used as a framework for the identification of the respondents' approaches to 


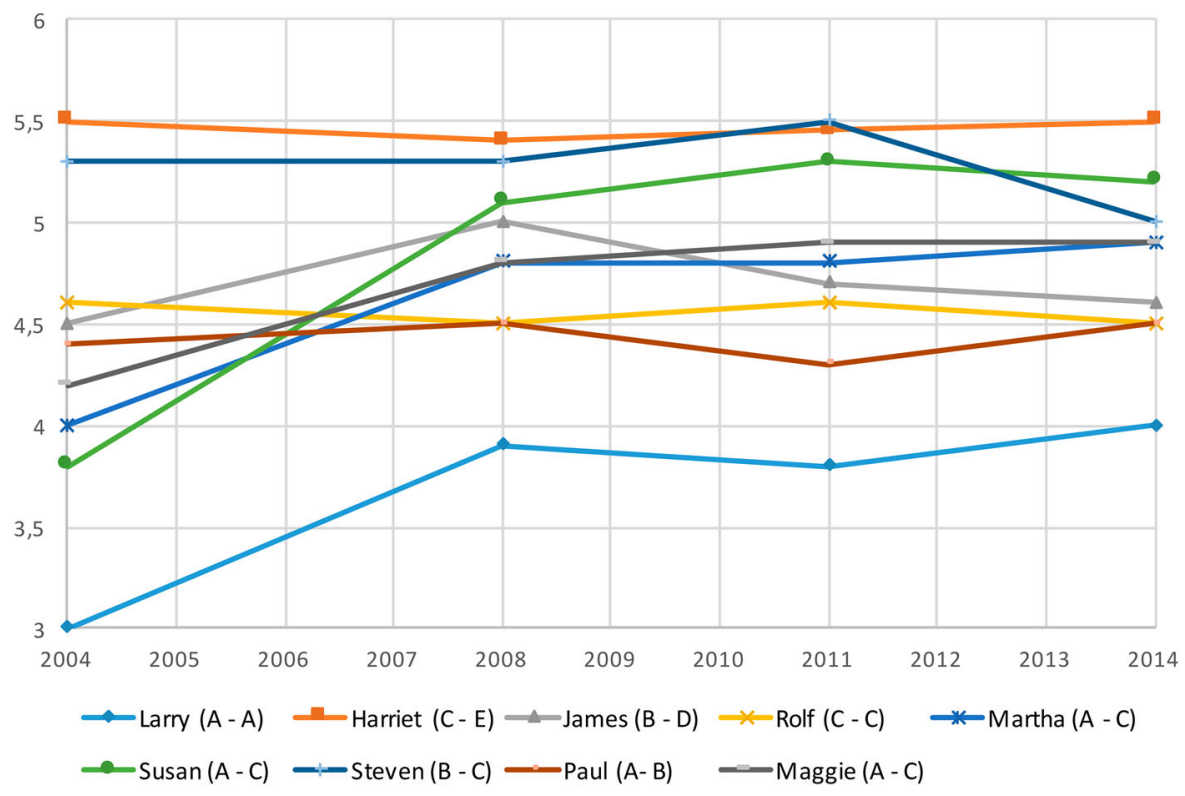

Figure 1. Student perception of teaching quality.

teaching at the four periods in time. These categories are described in Table 4 together with corresponding categories for approaches to teaching with technology (ATT). The ATT categories were extrapolated from the categories proposed by Trigwell and colleagues (1994) using data from the present investigation to include approaches to teaching with Edtech. Excerpts from interviews have been used to illustrate the categories of approaches to teaching and teaching with technology.

Although phenomenographic research methods are purely qualitative, they can also provide the basis for quantitative measures of conceptions of and approaches to teaching (Micari, Light, Calkins, \& Streitwieser, 2007). By comparing categories over time, it is possible to identify changes, which can then be represented quantitatively (Table 5).

\section{Results}

Table 5 illustrates changes in the approaches to teaching of the respondents over time, which correspond to the teachers' conceptual changes (Trigwell \& Prosser, 1996), where $\mathrm{AT}=$ approach to teaching and ATT = approach to teaching with technology. A, $\mathrm{B}, \mathrm{C}, \mathrm{D}$ and $\mathrm{E}$ refer to the categories of approach to teaching as described by Trigwell and to the approaches to teaching with technology, found in this study (see Table 4). The respondents show great variation in both their approaches to teaching and in the degree to which their approaches have changed over time, some showing no change and others moving from a teacher-focused, transmission approach to a student-focused, facilitative approach. 
Table 4. Description of approaches to teaching (AT) and approaches to teaching with technology (ATT) categories $A$ to $E$ and examples of interview data that exemplify each category.

Approaches to teaching and learning (AT)

Approach A: Teacher-focused activity with the intention of transferring information to the students. The focus is on transmitting discipline-based facts and skills, but not on the relationships between them. No prior knowledge by students is assumed or that students need to be active in the learning process

Example Quite honestly I think that it's the student's role to quotes: listen and mine to talk, whether it's lectures or any other form of activity

Approach B: Teacher-focused activities with the intention of helping students acquire the main concepts and the relationships between them. Students do not need to be active in the learning process. Students' understanding of the subject matter is built through working within the predetermined teacher and/or content framework structures

Example It's important that the students are with you, that you quotes: don't leave them behind but test the waters now and then to see if everyone has understood, or if you need to back up a bit, take something again or if you can continue

Approach C: This approach focuses on interaction between the teacher and students aimed at helping students acquire concepts and understand their relationships. Students' knowledge is gained through active engagement in the teaching-learning process and interaction between teacher and student

Example What the students need is to get an understanding of quotes: $\quad$ when and where certain theories and certain tools can be used. What's important is knowing how you solve problems and what the biggest pitfalls are

Approach D: An approach that focuses on students developing their own conceptions. Here the teacher adopts a student-focused strategy with the intention of assisting students to develop their own conceptions of the subject matter. The focus of student activity is on elaborating and extending students' understanding

Example I think I have a more consultative role as a teacher. I quotes: don't work very much with lectures, it's more about the students working together to develop their own knowledge; they should be able to use the material themselves and be able to communicate their knowledge to others

Approach E: This approach emphasises students changing their conceptions. The teacher adopts a student-focused strategy with the intention of helping students to both develop and change their conceptions of a phenomenon. The focus of student activity is on students' restructuring and changing their current world view by interacting with subject material in a way that challenges their currently held conceptions

Example I try to focus on the students, what problems they have quotes: $\quad$ understanding and why, to give them the tools they need to understand. Giving students the lead is one way I work, e.g. designing a lab where they have to construct their own methods. They need to gain a holistic view of the subject, to change their conceptions and grow
Approaches to teaching and learning with technology (ATT)

Activity is teacher-focused where technology is used to transmit information about the discipline. No interaction with students is anticipated. Of importance is the demonstration and delivery of discipline-based facts and skills using technology as a supplementary tool

Instead of standing and giving the same lectures on different courses and years, if you record the lecture the students can listen when they like

The focus of activity remains on the teacher disseminating discipline-based information. Different delivery strategies will assist students to understand the material. The teacher uses technology to help students acquire the concepts of the syllabus. Students' understanding of the subject matter is facilitated through working with predetermined content materials delivered via institutional technology channels

I've created an animation, a tabletting machine; since there is a limited time in the course I hope that this simulation will increase their understanding of what happens when the powder is compressed into a tablet and that it is quite complex

As approach B but with the addition of dialog with students in the learning process using communication technologies. Students are introduced to activities such as digital simulations, project work and group discussions

It's important to create possibilities for dialog between students, and with us teachers. And with the technology available today it's pretty easy to create such networks

The teacher uses technology for collaboration and communication with students and between students. Problem-based approaches may be used where students can create their own digital resources. Virtual worlds are used to create authentic learning environments where students are co-creators of knowledge

For me it feels as if there are always two parts [to teaching]: presenting information that helps the students with a virtual lab for example, but also the process, how the group thinks when they are working with these labs, their collaboration and discussions

Students design and create their own scenarios through virtual worlds or audio/video recordings. Curriculum and learning resources are created jointly by teacher and students. Open educational resources and social media are used in the learning process. Communication, creation and delivery of digital resources are student-led. The use of technology is aimed at helping students prepare themselves for their future roles and careers Especially where activities in OpenSim are concerned, my role is very different. It's more a partnership between the students and myself to create knowledge and understanding to strengthen them in their future role as pharmacists 
Table 5. Changes in approaches to teaching among respondents.

\begin{tabular}{|c|c|c|c|c|c|c|c|c|c|}
\hline \multirow[b]{2}{*}{ Respondent } & \multicolumn{2}{|c|}{2004} & \multicolumn{2}{|c|}{2008} & \multicolumn{2}{|c|}{2011} & \multicolumn{2}{|c|}{2014} & \multirow[b]{2}{*}{ Change } \\
\hline & AT & $A \Pi$ & AT & ATT & AT & $A \Pi$ & AT & ATT & \\
\hline Larry & A & A & - & - & - & - & A & A & 0 \\
\hline Harriet & - & - & $C$ & C & D & D & $\mathrm{E}$ & $\mathrm{E}$ & +2 \\
\hline James & - & - & B & B & D & C & D & D & +2 \\
\hline Rolf & C & C & C & $C$ & C & $C$ & C & $C$ & 0 \\
\hline Martha & A & A & B & B & - & - & $\mathrm{C}$ & $C$ & +2 \\
\hline Susan & A & A & B & B & B & B & $\mathrm{C}$ & $C$ & +2 \\
\hline Steven & B & C & B & C & B & $C$ & $\mathrm{C}$ & $C$ & +1 \\
\hline Paul & A & A & $\mathrm{B}$ & B & B & B & B & B & +1 \\
\hline Maggie & A & A & - & - & B & B & C & $\mathrm{C}$ & +2 \\
\hline
\end{tabular}

\section{No change (0)}

Both Larry (approach A) and Rolf (approach C) display no change in their approaches to teaching or approaches to teaching with technology, but reasons for their lack of development differ. Both are experienced teachers and have taught campus-based courses for many years, although Rolf also has considerable previous experience of teaching with technology.

For Larry, teaching is about the transmission of information. In terms of teaching with technology, his concerns are mainly focused on technical aspects such as the quality of recorded lectures. Further, his online course material has not changed in 10 years, apart from small adjustments. Larry experiences both challenges and advantages when teaching with Edtech, but does not seem motivated to seek solutions to challenges such as lack of contact with students:

What's negative is that it is boring not to meet the students. What's positive is being able to manage your time better and illustrate some things better, such as animations. (Interview 2004)

For Rolf, on the other hand, who has a more student-focused approach to teaching, communication and dialog with students with the aim of helping them to understand concepts are necessary:

I believe that accessibility is a key concept, that the students experience that the teacher is there, that I can give them the support they need right there and then to understand. (Interview 2004)

However, where Larry perceives the physical distance to students as negative, Rolf uses Edtech to bridge the distance and maintain dialog and communication with students.

You often have just as much contact with online students as with campus students, since you can communicate with them through the learning platform, through chat, email and so on. (Interview 2008)

According to interview data, neither Larry nor Rolf seem to participate in discussions with colleagues on teaching and learning; they are not part of the departmental teaching discourse. 


\section{Incremental change (+1)}

Both Steven and Paul are also experienced teachers; however, their approaches to teaching with technology do show some change. Paul moves from an entirely teacher-focused approach to an approach that also considers the students' learning needs (A to B), and Steven's approach develops to include more interaction and dialog with students and a greater focus on their needs (B to C).

Although Paul is an experienced teacher, working on the BSc Pharm was his first encounter with Edtech:

I didn't understand the first year how net-based courses worked. It's been a lot better this year when I knew more. I thought it was very enjoyable and varied to teach in this way, it gives new impulses and ideas for teaching. I had to think differently. (Interview 2004)

Paul was positive to using Edtech and teaching online, but initially considered his lack of experience with technology as a disadvantage and adopted a teaching approach based on face-to-face teaching experience:

It's positive being forced to create material that is more thought-out than usual. I've learnt a lot about how to use the different [technology] tools and what I can use them for in my teaching ... and, well, it's clearly another way of teaching than when I give lectures on campus. (Interview 2011)

Teaching with Edtech was also new to Steven at the outset. His conception of teaching with technology was positive, although his approach was initially teacher-focused, considering mainly the advantages to himself:

You are freer as teachers since you can better, I think, plan your time. And it's possible to combine some travel with online teaching and tutoring. (Interview 2008)

Although developing a more student-focused approach, he experienced communication as challenging:

To check that students have understood. [...] That can sometimes be very, very difficult on an online course. Communication is important; there are so many different students, from different backgrounds. (Interview 2011)

\section{Change and development (+2)}

The greatest change in approaches to teaching and learning can be seen in Harriet, James, Martha, Susan and Maggie.

Harriet ( $\mathrm{C}$ to $\mathrm{E}$ ) had some prior experience of teaching; however, introducing Edtech into her teaching was a challenge:

When I started I would have preferred teaching in a classroom, but the program is online and I was 'forced' to think distance! It was probably an advantage. It meant that I understood the importance of clear information, [...] having continual contact with students and what solutions worked best online in practice. (Interview 2008)

She participated in professional development activities, interacted with colleagues and very quickly developed her approach to teaching with technology: 
You have to have a clear picture of what you want to do pedagogically; why should I put this extra step in, or this additional technology. When I decided to try virtual reality [OpenSim] I had a clear need, I did not want to bring the students to campus, but they needed to train communication. I had to find another solution. (Interview 2011)

Harriet's conceptions of technology and teaching became increasingly positive and she sought to develop expertise also in the field of teaching and learning:

I realise now the advantages of working as an online teacher, things that are obvious to me, but things most teachers don't think about. Especially my experience with technology and how to work with it, see through it; that you can ignore the technology and still have an interesting meeting with people. [...] What is interesting is that my focus has changed from a strong interest in my subject to the pedagogy part of ICT and education, it has been really exciting. (Interview 2014)

James (B to D) also had very little previous teaching experience, but quickly developed his approaches to teaching to become more student-focused:

I think web-based learning has changed my view of my role as a teacher. [...] My role as a teacher is that I rely on the body of knowledge and facts contained in the book and try to put the words and theory into perspective, but mostly to help students to think about how to use their knowledge - how does that way of thinking work and what does it lead to? (Interview 2014)

For three of the teachers, Martha, Susan and Maggie, teaching on the online BPharm was also the beginning of their teaching careers. Martha expressed this very clearly:

We were several people employed at the same time and none of us had ever taught. There were no senior lecturers who we could ask. We did what we did but we had no connection to how others did things. (Interview 2008)

The teaching approach adopted by all three was initially teacher-focused (A) and to a large extent based on their own experiences as students. Changes in their conceptions and approaches to teaching were gradual but consistent. As Susan explained, things did not always work out in the beginning:

The very first course I had in 2003 didn't work well. I think it was because I didn't know how things worked with web-based education. It was new. It was hard. I didn't really understand what the students needed. (Interview 2004)

... what has changed is that I understand more, think a little bit more that they are out there. As an online teacher you need to show yourself, be visible, you should show that you are available to answer questions etc. I think this is where I've changed most as a teacher, accessibility and visibility. (Interview 2008)

Both Susan and James also experimented with other uses of technology and in 2011 developed online simulations to illustrate the tabletting process and a chromatography simulation.

Martha expressed a change in her conceptions of teaching with technology:

I also think more about the students' learning process 'now I want to bring up this topic here, how should I do it? What kind of activity would help?' I don't think I thought so in the beginning. (Interview 2014)

And Maggie about a virtual hospital for her students: 
I think that my students won't know so much when they begin the clinical pharmacy course, so I see virtual reality [OpenSim] as an opportunity to mimic a medical rounds situation so that they can practice their role as pharmacist. (Interview 2014)

\section{Student satisfaction}

Figure 1 shows the relationship between student satisfaction and teachers' approaches to teaching over time (2004, 2008, 2011 and 2014) and Table 6 shows the response rates to the student satisfaction questionnaire. Student satisfaction can be seen to mirror teaching approaches. Where the teachers' approach to teaching is more student-focused, student satisfaction tends to be greater.

Overall, satisfaction with the quality of teaching increases for all of the respondents, but perhaps surprisingly it also increases for Larry, despite there being no change in his approach to teaching. Although phenomenographic interview data provide a description of a teaching approach, it does not take into account how well the approach is carried out. Thus, Larry may improve his delivery over time without changing his teaching approach. Correspondingly, teachers who develop their approaches may initially experience a reduction in student satisfaction (Walder, 2015) as they implement new and unfamiliar methods. This is true for Harriet, Maggie, James and Susan; although the level of student satisfaction generally increases, it drops somewhat when they introduced new pedagogies and technology into their courses.

\section{Discussion}

In this longitudinal study, the objective was to reveal the variation and changes in conceptions of and approaches to teaching with technology over time of teachers in HE. The study has shown that the novice teachers developed their conceptions of and approaches to teaching with technology, which in turn are related more to studentcentred approaches, while their more established colleagues failed to do so.

Where change does occur, it is long term and gradual. The respondents displaying no change seem to have reached pedagogical inertia; they consider their teaching approach to be adequate and not requiring change. For change to occur, it can require powerful new influences such as the introduction of new technologies or economic constraints to challenge this inertia (Barnett, 2014). For some, the opportunity to take part in developmental

Table 6. Student response rates to CEQ.

\begin{tabular}{lcccr}
\hline & \multicolumn{3}{c}{ Number of student responses and response rate } \\
\cline { 2 - 4 } Respondents & 2004 & 2008 & 2011 & 2014 \\
\hline Larry & $45(55 \%)$ & $48(78 \%)$ & $39(68 \%)$ & $35(61 \%)$ \\
Harriet & $37(78 \%)$ & $28(69 \%)$ & $17(65 \%)$ & $15(60 \%)$ \\
James & $37(40 \%)$ & $32(46 \%)$ & $5(50 \%)$ & $15(54 \%)$ \\
Rolf & $71(71 \%)$ & $46(63 \%)$ & $20(55 \%)$ & $32(59 \%)$ \\
Martha & $50(50 \%)$ & $20(48 \%)$ & $14(29 \%)$ & $34(60 \%)$ \\
Susan & $59(60 \%)$ & $30(64 \%)$ & $14(29 \%)$ & $14(52 \%)$ \\
Steven & $71(71 \%)$ & $46(63 \%)$ & $57(68 \%)$ & $32(59 \%)$ \\
Paul & $71(83 \%)$ & $47(62 \%)$ & $57(68 \%)$ & $35(61 \%)$ \\
Maggie & $51(56 \%)$ & $30(64 \%)$ & $5(50 \%)$ & $12(50 \%)$ \\
\hline
\end{tabular}


projects provided the pedagogical impetus for change, while for others the desire to improve their teaching skills was sufficient.

The most experienced teachers in the study, Larry, Rolf, Paul and Steven, exhibited little to no change. Ertmer (2005) found that changing (senior) teachers' attitudes towards student-centred learning is a difficult and complex process. Postareff, Lindblom-Ylänne, and Nevgi (2007) also observed resistance to change among more experienced teachers. This lack of change may reflect the research pressures that senior academics face in order to gain promotion, limiting their investment of time and motivation in pedagogical development.

The novice teachers in the study (Susan, Martha and Maggie), however, demonstrated greater change in their conceptions of and approaches to teaching. It is probable that beginning teaching with Edtech was easier for them since they had no preconceptions of teaching. However, when teachers are inexperienced with teaching with technology, they frequently base their initial development of teaching on their overall pedagogical beliefs (Stein, Shephard, \& Harris, 2011) and model their own teaching on that which they themselves experienced (Shulman, 2005). Although the novice teachers initially had a more teacher-focused approach, they were able to develop and change more rapidly than experienced colleagues. Novice teachers are more malleable in terms of their ability to change their conceptions and approaches. Therefore, the adoption of a blanket approach to the academic development of novices, as they enter the HE teaching profession, should reduce the need for educational developers to later 'undo' more teacher-centred approaches, inherited from their own experiences as students.

There is of course also a pressing need to support the development of experienced teachers who already have a deeply entrenched, frequently teacher-centred teaching approach. Teacher professional development is needed to support conceptual change and improve the use of Edtech for both categories. However, focusing professional development activities on novice/early career academics as they enter the profession is likely to lead to a more lasting and progressive impact on the field. By supporting HE teachers in the task of changing their conceptions of teaching and learning, a more effective use of Edtech can be achieved and the lack of educational gains made since the digital revolution became a part of HE may be remedied (Åkerlind, 2003; Kim et al., 2013; Trigwell \& Prosser, 2004).

In the future, this study could profitably be elaborated by further research into the sociocultural context of the teaching environment to investigate the contextual factors that contribute to changes in teachers' conceptions of and approaches to teaching and learning with Edtech.

\section{Disclosure statement}

No potential conflict of interest was reported by the authors.

\section{Notes}

1. 'Educational technology is the study and ethical practice of facilitating learning and improving performance by creating, using and managing appropriate technological processes and resources.' AECT committee in Januszewski and Molenda (2008). 
2. A commercial VLE, Ping Pong was used. http://pingpong.se/index.en.html.

3. Adobe Connect http://connect-innovation.com/adobe-connect/meetings.

4. A virtual environment including a pharmacy and hospital created in Open Simulator http:// opensimulator.org/wiki/.

5. Statistics obtained from the university personnel dept.

6. Statistics obtained from the university personnel dept.

\section{ORCID}

Claire Englund (D) http://orcid.org/0000-0003-3448-7964

Anders D. Olofsson (D) http://orcid/org/0000-0001-8409-0557

Linda Price (D) http://orcid/org/0000-0001-5291-0469

\section{References}

Åkerlind, G. (2003). Growing and developing as a university teacher - variation in meaning. Studies in Higher Education, 28(4), 375-390.

Barnett, R. (2014). Thinking about higher education. In P. Gibbs \& R. Barnett (Eds.), Thinking about Higher Education (pp. 9-22). New York and London: Springer International Publishing Switzerland.

Benton, S.L., Cashin, W.E., \& Kansas, E. (2012). Student ratings of teaching: A summary of research and literature (IDEA PAPER\# 50). Retrieved December 5, 2015, from http://citeseerx.ist.psu. edu/viewdoc/summary?doi=10.1.1.388.8561

Biggs, J. (1999). What the student does: Teaching for enhanced learning. Higher Education Research \& Development, 18(1), 57-75.

British Educational Research Association. (2011). Ethical guidelines for educational research. Retrieved May 12, 2015, from https:/www.bera.ac.uk/wp-content/uploads/2014/02/BERAEthical-Guidelines-2011.pdf?noredirect=1

Cohen, L., Manion, L., \& Morrison, K. (2011). Research methods in education. Abingdon: Routledge.

Conole, G. (2014). The use of technology in distance education. In O. Zawacki-Richter \& T. Anderson (Eds.), Online distance education: Towards a research agenda (pp. 217-236). Edmonton: Athabasca University Press.

Conole, G., de Laat, M., Dillon, T., \& Darby, J. (2008). 'Disruptive technologies', 'pedagogical innovation': What's new? Findings from an in-depth study of students' use and perception of technology. Computers \& Education, 50(2), 511-524.

Cope, C., \& Ward, P. (2002). Integrating learning technology into classrooms: The importance of teachers' perceptions. Educational Technology \& Society, 5(1), 67-74.

Creswell, J.W. (2002). Educational research: Planning, conducting, and evaluating quantitative. Upper Saddle River: Prentice Hall.

Drent, M., \& Meelissen, M. (2008). Which factors obstruct or stimulate teacher educators to use ICT innovatively? Computers \& Education, 51(1), 187-199.

Errington, E. (2004). The impact of teacher beliefs on flexible learning innovation: Some practices and possibilities for academic developers. Innovations in Education and Teaching International, 41(1), 39-47.

Ertmer, P. (2005). Teacher pedagogical beliefs: The final frontier in our quest for technology integration? Educational Technology Research and Development, 53(4), 25-39.

Ertmer, P., \& Ottenbreit-Leftwich, A. (2013). Removing obstacles to the pedagogical changes required by Jonassen's vision of authentic technology-enabled learning. Computers \& Education, 64(2013), 175-182.

Fanghanel, J., \& Trowler, P. (2008). Exploring academic identities and practices in a competitive enhancement context: A UK-based case study. European Journal of Education, 43(3), 301-313. 
Glassett, K., \& Schrum, L. (2009). Teacher beliefs and student achievement in technology-rich classroom environments. International Journal of Technology in Teaching and Learning, 5(2), 138153.

Hawthorne, N., \& Anderson, C. (2009). The global pharmacy workforce: A systematic review of the literature. Human Resources for Health, 7(1), 1-8.

Januszewski, A., \& Molenda, M. (2008). Educational technology: A definition with commentary. New York: Routledge.

Kember, D. (1997). A reconceptualisation of the research into university academics' conceptions of teaching. Learning and Instruction, 7(3), 255-275.

Kember, D., \& Gow, L. (1994). Orientations to teaching and their effect on the quality of student learning. The Journal of Higher Education, 65(1), 58-74.

Kember, D., \& Kwan, K.-P. (2000). Lecturers' approaches to teaching and their relationship to conceptions of good teaching. Instructional Science, 28(5), 469-490.

Kim, C., Kim, M.K., Lee, C., Spector, J.M., \& DeMeester, K. (2013). Teacher beliefs and technology integration. Teaching and Teacher Education, 29(2013), 76-85.

Kirkwood, A. (2009). E-learning: You don't always get what you hope for. Technology, Pedagogy and Education, 18(2), 107-121.

Kirkwood, A., \& Price, L. (2006). Adaptation for a changing environment: Developing learning and teaching with information and communication technologies. The International Review of Research in Open and Distance Learning, 7(2), 1-14.

Kirkwood, A., \& Price, L. (2012). The influence upon design of differing conceptions of teaching and learning with technology. In Informed design of educational technologies in higher education: Enhanced learning and teaching (pp. 1-20).

Kirkwood, A., \& Price, L. (2013). Examining some assumptions and limitations of research on the effects of emerging technologies for teaching and learning in higher education. British Journal of Educational Technology, 44(4), 536-543.

Kreber, C., \& Kanuka, H. (2013). The scholarship of teaching and learning and the online classroom. Canadian Journal of University Continuing Education, 32(2), 109-131.

Krumsvik, R.J. (2014). Teacher educators' digital competence. Scandinavian Journal of Educational Research, 58(3), 269-280.

Laurillard, D. (2008). Technology enhanced learning as a tool for pedagogical innovation. Journal of Philosophy of Education, 42(3-4), 521-533.

Laurillard, D., \& Masterman, E. (2009). TPD as online collaborative learning for innovation in teaching online learning communities and teaching professional development: Methods for improved educational delivery. Berlin: Springer.

Lindberg, O., \& Olofsson, A. (2012). Sustaining a professional dimension in the use of educational technology in European higher educational practices. Educational Technology, 52(2), 34-38.

Marsh, H.W. (1987). Students' evaluations of university teaching: Research findings, methodologi$\mathrm{cal}$ issues, and directions for future research. International Journal of Educational Research, 11(3), 253-388.

Micari, M., Light, G., Calkins, S., \& Streitwieser, B. (2007). Assessment beyond performance phenomenography in educational evaluation. American Journal of Evaluation, 28(4), 458-476.

Norton, L., Richardson, T., Hartley, J., Newstead, S., \& Mayes, J. (2005). Teachers' beliefs and intentions concerning teaching in higher education. Higher Education, 50(4), 537-571.

Olofsson, A., \& Lindberg, O. (2014). Introduction. Technology, Pedagogy and Education, 23(3), 285-291.

Orlando, J. (2014). Teachers' changing practices with information and communication technologies: An up-close, longitudinal analysis. Research in Learning Technology, 22:21354.

Ottenbreit-Leftwich, A.T., Glazewski, K.D., Newby, T.J., \& Ertmer, P.A. (2010). Teacher value beliefs associated with using technology: Addressing professional and student needs. Computers \& Education, 55(3), 1321-1335.

Postareff, L., Lindblom-Ylänne, S., \& Nevgi, A. (2007). The effect of pedagogical training on teaching in higher education. Teaching and Teacher Education, 23(5), 557-571. 
Price, L. (2014). Modelling factors for predicting student learning outcomes in higher education. In D. Gijbels, V. Donche, J. T. E. Richardson, \& J. D. Vermunt (Eds.), Learning patterns in higher education: Dimensions and research perspectives (pp. 56-77). London: Routledge.

Price, L., \& Kirkwood, A. (2014a). Informed design of educational technology for teaching and learning? Towards an evidence-informed model of good practice. Technology, Pedagogy and Education, 23(3), 325-347.

Price, L., \& Kirkwood, A. (2014b). Using technology for teaching and learning in higher education: A critical review of the role of evidence in informing practice. Higher Education Research \& Development, 33(3), 549-564.

Prosser, M., \& Trigwell, K. (1999). Relational perspectives on higher education teaching and learning in the sciences. Studies in Science Education, 33(1), 31-60.

Ramsden, P. (1991). A performance indicator of teaching quality in higher education: The course experience questionnaire. Studies in Higher Education, 16(2), 129-150.

Schneckenberg, D. (2009). Understanding the real barriers to technology-enhanced innovation in higher education. Educational Research, 51(4), 411-424.

Schneckenberg, D. (2010). Conceptual foundations and strategic approaches for ecompetence. International Journal of Continuing Engineering Education and Life Long Learning, 20(3), 290-305.

Scott, K.M. (2016). Change in university teachers' elearning beliefs and practices: A longitudinal study. Studies in Higher Education, 41(3), 1-17.

Selwyn, N. (2007). The use of computer technology in university teaching and learning: A critical perspective. Journal of Computer Assisted Learning, 23(2), 83-94.

Selwyn, N. (2010). Looking beyond learning: Notes towards the critical study of educational technology. Journal of Computer Assisted Learning, 26(1), 65-73.

Shulman, L. S. (2005). Signature pedagogies in the professions. Daedalus, 134(3), 52-59.

Somekh, B. (2008). Factors affecting teachers' pedagogical adoption of ICT international handbook of information technology in primary and secondary education (pp. 449-460). New York: Springer Verlag.

Song, Y., \& Looi, C.-K. (2012). Linking teacher beliefs, practices and student inquiry-based learning in a CSCL environment: A tale of two teachers. International Journal of Computer-Supported Collaborative Learning, 7(1), 129-159.

Spooren, P., Brockx, B., \& Mortelmans, D. (2013). On the validity of student evaluation of teaching: The state of the art. Review of Educational Research, 83(4), 598-642.

Stanfors, M. (2007). Feminization and professionalization of pharmacies in Sweden. Business and Economic History On-Line, 5, 1-21.

Stein, S. J., Shephard, K., \& Harris, I. (2011). Conceptions of e-learning and professional development for e-learning held by tertiary educators in New Zealand. British Journal of Educational Technology, 42(1), 145-165.

Swedish Ethical Review Board, E. (2004). Ethical Review Act (2003:460). Retrieved June 10, 2015, from http://www.epn.se/en/start/

Thurmond, V.A. (2001). The point of triangulation. Journal of Nursing Scholarship, 33(3), 253-258.

Trigwell, K., \& Prosser, M. (1996). Changing approaches to teaching: A relational perspective. Studies in Higher Education, 21(3), 275-284.

Trigwell, K., \& Prosser, M. (2004). Development and use of the approaches to teaching inventory. Educational Psychology Review, 16(4), 409-424.

Trigwell, K., Prosser, M., \& Taylor, P. (1994). Qualitative differences in approaches to teaching first year university science. Higher Education, 27(1), 75-84.

Walder, A.M. (2015). Obstacles to innovation: The fear of jeopardising a professorial career. British Journal of Education, 3(6), 1-16. 